\title{
CAREERS
}

TRADE TALK How a science educator moved from research lab to teaching lab p.119
SCIENCE COMMUNICATION Opportunities for public engagement go.nature.com/zex87n
NATUREJOBS For the latest career listings and advice www.naturejobs.com

\section{The power of a pastime}

From painting to punching to aeroplane-jumping, the hobbies that scientists pursue offer a vital escape from the laborious life of the lab.

\section{BY CHRIS WOOLSTON}

A lbert Einstein mastered the violin. Richard Feynman banged bongos. Following in the tradition of multi-talented physicists, Federica Bianco likes to take a break from her research to punch people in the face. Bianco, an avid boxer who is also an astrophysicist at New York University, flew to Richmond, California, for her first professional bout in April. It did not go well for her opponent. Bianco pinned her competitor to the ropes with a flurry of punches and did not let up until the referee called the fight. It took just one minute and twenty seconds. "I didn't want to stop, but she was taking too much punishment," Bianco says.
For Bianco, boxing is not just a hobby; it is a total mind-and-body escape from her work. "As a scientist, I'm thinking about all sorts of things all the time," she says. “The ring is quiet. You get tunnel vision. The other person is trying to take off your head and you have to deal with that."

At a time when competition for science funding and job promotions sometimes resembles a boxing match, many researchers have trouble conceiving of an active life outside the lab. Indeed, there can be subtle or not so subtle - pressures to sacrifice leisure time and put aside other interests for the sake of the next experiment, paper or conference talk. But many scientists say that their pastimes make them better researchers by sharpening their minds, building confidence and reducing stress. Their experiences should offer hope to researchers who are feeling overwhelmed by the pressure of their jobs. Release can be just a ride, jump, joke or punch away.

To be sure, some senior researchers in academia and other sectors still look askance at hobbies or leisure activities. Ryan Raver, now a product manager at the biotechnology firm Sigma-Aldrich in St Louis, Missouri, recalls an instance at the University of Wisconsin-Madison when he heard that one of the members of his thesis committee had commented that he thought Raver had spent too much time blogging and playing lead guitar in a hard-rock band. "He thought I should have been more 
> focused on my work," Raver says. "But playing in the band helped me survive grad school. It kept my excitement and motivation up. It pushed me through the day."

Sean Carroll, a physicist at the California Institute of Technology in Pasadena, wrote a blogpost advising scientists to choose their hobbies carefully, especially if they ever want to win tenure. Specifically, he counsels them to stay away from pastimes that could drain attention from science. "You are better off if your hobbies are nothing like your work," he writes. "Permissible hobbies include skydiving, playing guitar, or cooking. Suspicious hobbies include writing of any sort (novels, magazine articles, blogs), programming or web stuff, starting a business, etc. Why? Because there's a feeling that this kind of activity represents time that could be spent on research."

Carroll, who in 2005 was denied tenure at a different institution, says in his blogpost that he regrets the time and effort that he put into writing Spacetime and Geometry: An Introduction to General Relativity (Addison-Wesley, 2003), a textbook that did not win him many points in scientific circles. In the blogpost, he deems the book "probably the worst thing I did personally".

Raver says that he had a much easier time following his outside passions once he left academia for an industry job. "Professors and academics want you to believe that the more hours you put in, the more likely it is that you'll have quality data," he says. "But people aren't machines. They need to take breaks and reset their minds when things get tough."

\section{FIGHT SCIENCE WITH SCIENCE}

There is plenty of evidence that scientific research and leisure pursuits can coexist. A study published in 2008 found that Nobel prizewinners were more likely than other scientists or members of the public to have long-standing hobbies. Notably, the prizewinners were about 1.5 times more likely to actively pursue arts and crafts than were members of the US National Academy of Sciences(R. Root-Bernstein et al. J. Psychol. Sci. Technol. 1, 51-63; 2008). For this sample, hobbies turned out to be better predictors of Nobel-level greatness even than reported IQ, which does not vary much between 'top' and 'average' scientists.

Robert Root-Bernstein, a physiologist at Michigan State University in East Lansing and lead author of the study, says that it is hard to know whether hobbies themselves help to fuel genius or whether geniuses are simply more likely to take up hobbies (see 'The secret lives of polymaths'). "It's probably some combination," he says. He also notes that, contrary to public opinion, scientific masterminds tend to be more adventurous, daring and physically vigorous than are members of the general

\section{NOBLE PASTIMES}

\section{The secret lives of polymaths}

The ranks of Nobel prizewinners in the sciences include many artists, musicians, athletes and writers. Here are the hobbies of seven notable Nobel laureates - and one single-minded exception.

Frederick Banting, who shared the 1923 Nobel Prize in Physiology or Medicine for his co-discovery of insulin, left behind hundreds of paintings and sketches when he was killed in a plane crash at the age of 49. One of his oil paintings sold for more than US\$76,000 in 2008.

In addition to playing the bongos, Richard Feynman, who shared the Nobel Prize in Physics in 1965 for his work on quantum electrodynamics, sketched and painted under the pseudonym Ofey. Female nudes were a common subject.

\footnotetext{
Albert Einstein could play Beethoven sonatas on his violin when he was a teenager and he performed at many benefit concerts in his later years. He once said that "life without playing music is inconceivable to me".
}

Carol Greider, who shared the 2009 Nobel Prize in Physiology or Medicine for her groundbreaking work with chromosome telomeres, is a dedicated athlete who has competed in several triathlons.

May-Britt and Edvard Moser, a married couple who shared the 2014 Nobel Prize in Physiology or Medicine for their discovery of the neural grid cells that help humans and other animals to navigate their surroundings, are avid mountain climbers who got engaged on the summit of Mount Kilimanjaro in Tanzania.

Stefan Hell, co-recipient of the 2014 Nobel Prize in Chemistry for his work with fluorescent microscopy, is a saxophone enthusiast who specializes in jazz and improv.

In a 2007 interview, geneticist Elizabeth Blackburn told the journal Biotechniques that she did not really have any major pastimes outside of the lab. "People who love their work don't need hobbies," she said. "Work is your hobby." She went on to share the 2009 Nobel Prize in Physiology or Medicine. C.W. public. "An unexpectedly large number of Nobel laureates took up surfing when it came into fashion in the 1960s," he says.

Some in academia do appreciate the value of hobbies and leisure pursuits for earlycareer researchers, perhaps because they have discovered it for themselves. Tony Ryan, a chemist and pro-vice-chancellor of the fac-

"Permissible
hobbies include
skydiving,
playing guitar,
or cooking.
Suspicious
hobbies include
writing of
any sort."
ulty of science at the University of Sheffield, UK, has hired many scientists over the years. He has always been reluctant to offer a position to anyone who is so focused on research that she or he has no time for anything else. "We want to know that you're an A-1 excellent scientist, but we also want to know that you're a well-rounded person whom students will relate to," he explains.

He has his own obsession: despite the demands of his job, he logs about 8,000 kilometres on his bicycle every year. He bikes to and from work, and rides with a group of enthusiasts - who call themselves 'Common Lane Occasionals' - every Saturday morning. While pedalling, he likes to talk about prime numbers with a computer scientist, sometimes to the annoyance of other members of the group, which includes a tree surgeon, a plumber and a physician.

Ryan even brings his bike along to international conferences, whether in London or Hong Kong. "I can fold it up and pack it into a suitcase," he says. "Other people will bring bikes of their own. Cycling has become the new golf."

Similarly, Alexander Suh, an evolutionary biologist at Uppsala University in Sweden, packs his climbing gear for any conference that might be near a rock face or climbing wall (pretty much all of them). Suh, who has been engaging seriously in the sport for about three years, says that his hobby has been great for professional networking. "So many biologists are interested in rock climbing that you can meet up with someone anywhere you go," he says. "We talk about science and we talk about climbing." When he is on his home campus, Suh tries to squeeze in an hour or so of climbing "whenever work gets crazy". In addition to clearing his mind, scaling a wall helps to undo the physical toll of genomics research. "I get a caveman posture sitting in front of a computer all day," he says.

Many scientists enjoy climbing, but Maria Sapar prefers falling. A PhD student in molecular biology at Cornell University in Ithaca, New York, Sapar has made 147 skydiving jumps, with many more ahead not bad for someone who is a bit afraid of heights. "I'm not a big fan of roller coasters," 


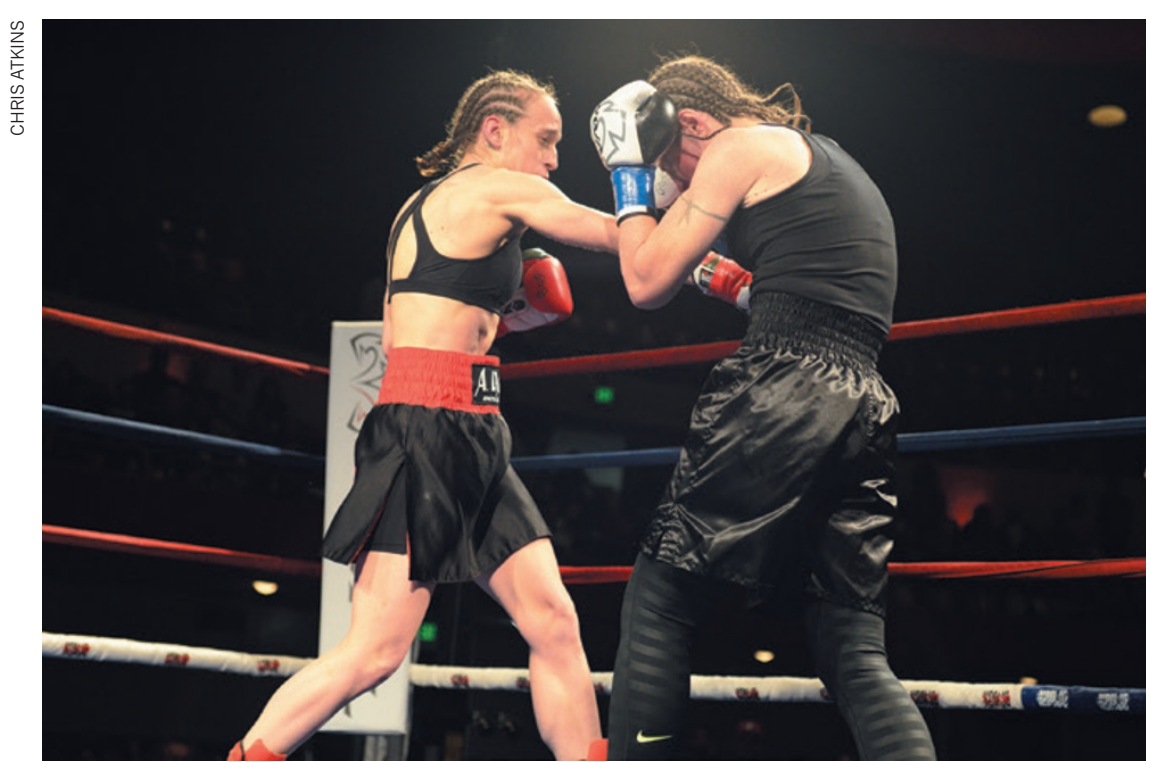

Astrophysicist Federica Bianco duels her opponent in a boxing match in Richmond, California.

she says. Fortunately, the vast distance to the ground does not necessarily register when she is leaning out of an aeroplane. "It's like looking at Google Maps," she says. Still, there is just enough risk and excitement to put the rest of her life - especially her research - in perspective. "When I'm scared or nervous about something in science, I think: Maria, you jump out of aeroplanes. You can do this."

Although skydiving falls into Carroll's category of 'permissible hobbies', Sapar does not talk much about her pastime in the lab, and has decided against putting it on her $\mathrm{CV}$. She reckons that future employers will care more about her research and publication history than her jump count, and there is always the chance that someone might take a negative view of her hobby. "When I tell people about it face to face, I always get one of two reactions. It's either, 'Oh, that's cool, or 'Why would you ever do that?"'

Adam Ruben, a malaria-vaccine researcher with the biotechnology company Sanaria in Rockville, Maryland, has had some scary moments of his own while practising his hobby: stand-up comedy. As a graduate student at Johns Hopkins University in Baltimore, Maryland, he would head to the city's clubs and bars to try out some jokes in front of often lessthan-impressed crowds. "I'd go to openmic nights where there were 30 other comedians and 5 audience members. It was terrible," he says. After moving to nearby Washington DC, he started to perform for bigger audiences that were receptive of the occasional foray into science humour.

Ruben still takes time away from his work to develop his act and perform live shows. In addition to one-liners, he often tells stories about his time as a $\mathrm{PhD}$ student, a topic that he mined heavily for his book, to Go to Grad School (Three Rivers Press, 2010). For example, he talks about the time that he worked three straight 21-hour days to provide data for an adviser's presentation. The twist - as many scientists in his audiences might guess - is that the data never got used. He says that he is generally happy with his education and scientific career, but he is also grateful that he has a platform through which to joke about its flaws. "Academia could use more humour," he says, even if some of that humour has a sharp point. "Only by complaining about something can you actually do something about it."

Like Ruben, Bianco is actively looking for gigs. She has yet to schedule her next bout, but is still devoting many hours to the ring. She spars with a partner several times a week, and she is always trying to get better. "Getting a $\mathrm{PhD}$ in physics made me a competitive person," she says. At first, she was worried that her fellow researchers might look down on her hobby. But the word is out about how she spends her time outside the lab, and she has been pleasantly surprised by the positive responses from both the boxing and physics communities. Boxers whom she meets are always amazed to learn that she is an astrophysicist, and physicists have been completely supportive of her pugilism. "Everyone is amused, interested and somehow, even proud," she says.

Depending on the setting, she is either a physicist-boxer or a boxer-physicist. Either way, she is proof that scientists can be more than their work, especially if they happen to have a wicked right hook.

Chris Woolston is a freelance writer in Billings, Montana.
Surviving Your Stupid, Stupid Decision
TRADE TALK Science educator

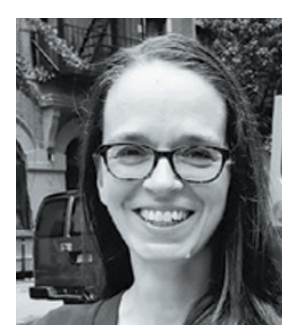

Elizabeth Waters

manages the outreach teaching laboratories at the Rockefeller University in New York City, where high-school students and their teachers can use state-of-theart equipment. She explains how boosting others' enthusiasm for and understanding of science builds on what she liked most about scientific research.

\section{What skills from the lab help you to do your job?}

As a researcher, I was fortunate enough to receive my own grant and manage the grant budget myself. I learned how to keep tasks and costs in line with the goals of the project. And learning how to establish collaborations with other researchers was very relevant to what I do now. Making sure that I understand other people's expectations of my role and their expectations of their role - that is really critical. All of the details around running a class smoothly depend on those skills.

\section{When did you first work with students?}

The lab that I worked in as a researcher at Rockefeller often hosted a high-school or college student. I asked for students to mentor and realized that I was starting to think more bigpicture about the students' research experience, working out what kinds of projects would be good for them. I did that because I loved to see other people have the opportunity to talk about science and get excited. Now, we're bringing students into labs that are just like those in which Nobel prizes have been won. The iterations of moving from training one student to the next gave me skills that I use all the time.

\section{How did you make it into a career?}

I started talking to lots of people when I was a postdoc, asking, 'What is your favourite part of your job?' I tried to identify the theme that really resonated most with me. Science education was at the top of my list. Then I tailored my CV. I volunteered to organize a yearly outreach event for fifth-graders, and taught a medical laboratory class at Hunter College in New York City, where I was an adjunct professor. Making time for those activities and for networking was not neglecting my research duties. It was serving my scientific career. see go.nature.com/gpmhxr for more. 